\title{
Sequential Explanatory Analysis of High School Teachers' Performance Observed From Self-Concepts, Teamwork and Visionary Leadership
}

\author{
H. TB. Urip Henus Surawardhana*, Soewarto Hardhienata, Rita Retnowati \\ Post Graduate Program, Universitas Pakuan Bogor, Indonesia \\ *Corresponding Author: H. TB. Urip Henus Surawardhana, Post Graduate Program, Universitas \\ Pakuan Bogor, Indonesia
}

\begin{abstract}
The purpose of this study is to find practical efforts to improve the performance of public Vocational High School teachers by examining the variables associated with them, namely self-concept, teamwork and visionary leadership. This study uses a sequential explanatory methods model and system analysis. The study population consisted of 350 public vocational high school teachers in the city of Serang, and a randomly selected sample with the formula of Taro Yamane was 187 people. Quantitative data were collected through questionnaires and statistical analysis methods using regression and correlation. The analysis of the system is used to help make recommendations and determine the priority order of the improvements needed. Qualitative data were collected through interviews, observations, documentation studies and focus group discussions. The results of the quantitative stage show that there are positive and significant relationships between the three independent variables and teacher performance, sequentially based on the strong relationship with the performance of the principal as follows: 1$)$ self-concept $\left(r_{y l}=0.789\right.$, $\rho<0.05)$; 2) visionary leadership $\left(r_{y 3}=0.745, \rho<0.05\right)$; and 3). Teamwork $\left(r_{y 2}=0.645, \rho<0.05\right)$, qualitative data shows the same tendency, that the improvement of principals' performance can be made through improving self-concept, teamwork and visionary leadership. The results of the analysis show that the priority components are improved from self-concept, teamwork, visionary leadership and teacher performance are: 1) self-behaviour, 2) self-acceptance, 3) self-identity, 4) physical perception, 5) future thinking, 6) spokespersons, 7) planners, 8) trainers, 9) goal alignment, 10) development of teamwork, 11) intensive communication, 12) focus on tasks, 13) implementation of learning, 14) assessment of learning, 15) learning planning 16) interpersonal skills.
\end{abstract}

Keywords: Teacher performance, Self Concept, Teamwork, Visionary Leadership, SITOREM

\section{INTRODUCTION}

The implementation of education will run well if it is supported by the ability of competent teachers, able to improve their performance, have high discipline and set an excellent example for their students. The role of teacher performance in carrying out their duties will support the implementation of a good education. Without excellent teacher performance, the application of education will not run as expected.

Teacher performance is one of the determinants of the high and low quality of education at the school level. Besides, a teacher must have abilities that include mastery of subject matter, professional mastery in the world of education. So that teacher performance is a work achievement carried out by the teacher in carrying out his duties as an educator so that a teacher must be smart and skilled shown by mastering good science, proper classroom management and having a good self-concept and leadership spirit.

In reality, the performance of teachers in schools is still low and needs to be further improved. An indication of the weak performance of teachers in schools is seen from the lack of desire to develop, increase self-competence, provide constructive suggestions for improving the quality of schools and the lack of appreciation and compliance with policies set by the school.

Based on the data in the preliminary study, it can be seen that the performance level of teachers in The Middle Vocational School of the City of Serang, obtained information that there are indications of 
teacher performance problems. Preliminary survey data from the Serang City Education Office, it is known that the performance level of teachers has only reached $58 \%$ and $60 \%$ over the two academic years, the survey results indicate that overall teacher performance in the Vocational School in Serang City is still not in good performance. Although there are several schools that show that teacher performance is in a sufficient category, overall teacher performance is not satisfactory. This indicates that the performance of teachers still needs to be improved so that excellent performance is achieved and can encourage the advancement of education.

In addition to the teacher's self-concept factor, the leadership style factor contributes to determining teacher performance in learning. In teaching teachers, leadership is an essential component in education, with good teacher leadership; it will be easier to direct and manage the class. A good teacher leadership style will be easier to lead and manage the class so that learning objectives can be adequately achieved. Another factor is teamwork, namely cooperation and mutual contribution by all parties, including colleagues, leaders, parents and students themselves to create an atmosphere of intelligent teamwork. To achieve success in teamwork, each team member must be able to do the work and have the ability to initiate discussions, seek information and opinions, propose procedures to achieve goals, elaborate opinions, and conclude to be an effort carried out as accountability of the tasks assigned mandated.

Based on the description above, it is important to strive for some effective ways to improve teacher performance through the development of components of variables related to it. This research will focus on efforts to improve the performance of principals through research on its relationship with the self-concept of teachers, teamwork and visionary leadership.

Based on the background, problem identification and problem limitation, the formulation of the problem in this study are:

- Is there a relationship between self-concept and teacher performance?

- Is there a relationship between visionary leadership and teacher performance?

- Is there a relationship between team works and teacher performance?

- Is there a relationship between self-concept, visionary leadership, and teamwork together with teacher performance?

\section{LITERATURE REVIEW}

\subsection{Teacher Performance}

Concerning the world of education, teacher performance can be defined as the extent to which a teacher works to the fullest following his abilities to achieve institutional goals. The ability of a teacher will be seen when teaching that can be measured by his teaching competence. The figure of a teacher is not just a functional job but is more professional, meaning that work is more closely related to the expertise and skills that have been prepared through the process of education and training specifically in their fields. According to research Darling (2010), states that most teacher who becomes the object of research think that the pedagogical and moral aspects of teaching are an important part of their daily duties. In the opinion of Muralidaran (2011) performance appraisal is divided into three main groups namely a) variations of teachers in applying to learn to students; $b$ ) evaluating teachers' perceptions and motivations in learning; c) evaluating effective performance appraisals. From this performance appraisal, it can be seen the extent of the teacher's performance in carrying out their duties

\subsection{Self-Concept}

According to Green (2015), the notion of self-concept tends to be an internal factor of the teacher which becomes the teacher's basic power. The concept of self is also the totality of the teacher's attitude and perception of himself. Taylor explains that self-concept is not an innate factor, but rather develops from a continuous and differentiated experience. Self-concept is an attempt by someone to get to know themselves. For a teacher, it is important to know and know who he is, because the more a teacher knows for what his existence in this world, the more he will make more meaning of the life he leads. 


\subsection{Teamwork}

According to Gualdenzop (2009) teamwork is an individual activity that works together in a cooperative environment to achieve the goals of a joint team through a variety of knowledge and skills. Teamwork can enhance collaboration and communication within and between parts of the organization. Teamwork usually consists of people who have different expertise so that it is used as strength in achieving organizational goals.

Lerner (2009) argues that a team is a collection of people who work with the same program. The work team in each organization is a major component in the implementation of integrated quality management to build trust, improve communication, and develop independence. According to Senior (2010), teamwork is a group whose individual efforts produce higher performance than the number of individual inputs. Teamwork generates positive synergies through a coordinated effort. This has the understanding that the performance achieved by a team is better than the performance per individual in an organization or a company.

\subsection{Visionary Leadership}

Teachers who have visionary leadership are teachers who have insight and understand the needs of their followers. To be someone who can lead well requires competence that supports his role as the spearhead of the organization. Competence is the ability or strength possessed by someone to support all their activities. According to Wang (2010) the visionary leader is seen from how he sees the future (futuristic thinking). Future thinking is seen in identifying new beliefs needed for leadership success in the decades to come.

Based on the study of theories and concepts relating to research variables, the hypothesis can be formulated as follows:

- There is a positive relationship between self-concept and teacher performance.

- There is a positive relationship between Teamwork and teacher performance.

- There is a positive relationship between visionary leadership and teacher performance.

- There is a positive relationship between self-concept, teamwork, and visionary leadership together with teacher performance.

\section{METHOdOLOGY}

This study uses a combined research method (Mixed Methods), which is a research method that combines quantitative methods, and qualitative methods to be used together in research activity, to obtain more comprehensive, valid, reliable and objective data. The method used in this study is a survey method with a correlational approach. The research variables consisted of three independent variables namely Self Concept $\left(X_{1}\right)$, Teamwork $\left(X_{2}\right)$, and Visionary Leadership $\left(X_{3}\right)$, while the dependent variable was Teacher Performance (Y). Data collection techniques at the qualitative research stage were carried out through in-depth interviews (in-depth interviews) with FGD (Focus Group Discussion) data, observations, and documentation studies. Furthermore, the implementation of the analysis and discussion of quantitative and qualitative research results apply the SITOREM method (Hardhienata, 2007). Based on the results of the SITOREM analysis it can be determined the priority of suggestions and action plans.

\section{RESULTS AND DISCUSSION}

\subsection{The Relationship between Self-Concept and the Performance of Vocational High School Teachers in Serang City}

The results of hypothesis testing showed the strength of the relationship between the Teacher's SelfConcept variables with Teacher Performance with a correlation coefficient value of 0.622 . This shows that each increase in the Teacher's Self Concept score increases the Performance of Vocational High School Teachers, besides that it means that $62.2 \%$ Vocational High School Teacher Performance is the result of the work of the Teacher's Self Concept while $37.8 \%$ is contributed by other variables has 
a relationship with improving Teacher Performance. Analysis of the regression equation $y=13.84+$ $0,81 \mathrm{X}_{1}$ is linear and otherwise significant, so this equation can be used to predict the performance of teachers through Self Concept.

When the teacher can conceptualize himself and understand the extent of his existence as a teacher through a variety of experiences, the teacher will also be able to arrange programs easily, manage, master and organize matters related to performance achievement indicators that are following educational goals. In its application, teacher performance can be achieved to the maximum if the teacher himself can recognize the positive and negative actions contained in himself and if it is done consistently and continuously it will result in the realization of a performance in the form of a quantity of work and good quality of work and according to expectations (Dee, 2015).

This is in line with the theory put forward by Dee (2015) which states that self-concept reflects one's tendency towards various aspects of his actions both positively and negatively. In the social learning theory approach, negative self-concepts are defined about the number of negative self-reinforcements. Instead, the positive self-concept is defined about the number of positive self-reinforcements.

The quantitative data above is strengthened by the results of observational data, interviews and documentation studies on qualitative research which can be concluded that the Self-Concept of Vocational High School teachers in Serang City observed has characteristics, characteristics and characteristics that are appropriate to the developing environment in each school that is the object research in order to improve the performance of vocational high school teachers in achieving the planned objectives. Therefore the Teacher's Self-Concept in qualitative data based on observations, observations and documentation in the field has the same tendency with the Teacher's Self-Concept in quantitative terms.

Based on the description above, it can be concluded that the higher the Teacher's Self-Concept will also increase the Teacher Performance results at school. Thus the findings of facts and data in the analysis of this study further support previous findings regarding the positive relationship between the Teacher's Self Concept and Teacher Performance.

\subsection{Relationship between Teamwork and Performance of Vocational High School Teachers}

The results of calculation of hypothesis testing show that there is a positive relationship between Teacher Teamwork and Teacher Performance with the regression equation is $=33.62+0.60 \mathrm{X}_{2}$. The coefficient of determination between Teacher Teamwork and Teacher Performance is equal to $r^{2}$.10.427 $=$. This means that teamwork contributed $42.7 \%$ to Teacher Performance, while $57.3 \%$ Teacher Performance was influenced by other factors.

Based on the above data calculation results, there are indications of the influence of teacher teamwork on teacher performance in carrying out their tasks and roles in the school with good teamwork in improving communication within and between parts of the organization. Likewise, with the teacher, as a teacher, there needs to be real action in building good cooperation in order to achieve educational goals. The collaboration can be in the form of fellow teachers, teachers with parents, teachers with students, and teachers with the school community environment.

Besides Taylor (2012), stated, teamwork is a group whose individual efforts produce higher performance than the number of individual inputs. Teamwork generates positive synergies through a coordinated effort. This has the understanding that teamwork can affect one's performance in working, in this case, teacher teamwork can affect teacher performance, so it can be concluded teacher performance can be influenced by teacher teamwork in carrying out their duties at school.

The quantitative data above is strengthened by the results of observational data, interviews and documentation studies on qualitative research and it can be concluded that the Vocational High School Teacher Teamwork in Serang City observed has characteristics, characteristics that are following the developing environment in each school that is the object of research. Therefore, Qualitative Teacher Teamwork in the field has the same tendency as Teacher Teamwork in quantitative terms.

Based on the description above, it can be concluded that the higher the Teamwork of Teachers, the results of the Teacher's performance at school will also increase. Thus, the findings of facts and data 
in the analysis of this study further enriched the research treasure and supported previous findings regarding the positive relationship between Teacher Teamwork and Teacher Performance.

\subsection{Relationship between Visionary Leadership and Vocational High School Teacher Performance}

Hypothesis test results show that there is a positive relationship between Teacher Visionary Leadership and Teacher Performance with the regression equation is $\hat{\mathrm{Y}}=32.94+0.68 \mathrm{X}_{3}$, for the value calculated $=230,89$ while $\mathrm{F}_{\text {table }}=3.89$, which means that the significance of the regression is very significant. The correlation coefficient between Teacher Visionary Leadership and Teacher Performance is equal to 0.555 . This means that visionary leadership contributes $55.5 \%$ to Teacher Performance, while $44.5 \%$ of Teacher Performance is influenced by other factors. Based on the results of the regression calculations it can be seen that Teacher Performance during school can be influenced by the Visionary Leadership style of Teachers. This shows that Visionary Teacher Leadership has a very important role in achieving teacher performance. The choice of leadership style used by a teacher can influence all the activities of group members and determine the group's ideology.

According to Senior (2010) the visionary leader is seen from how he sees the future (futuristic thinking). Future thinking is seen in terms of identifying new beliefs needed for leadership success in the next few decades. Relation to teacher performance visionary leadership teachers can create interesting visions for the future. This implies the understanding that teacher visionary leadership can affect one's performance at work so it can be concluded that teacher performance can be influenced by teacher visionary leadership in carrying out their duties in school like in other business entity as well as avoiding turnover (Al-Sharafi, \& Rajiani, I. 2013).

The results of the quantitative data above are strengthened by the results of observational data, interviews and documentation studies on qualitative research, so that it can be concluded that the visionary leadership of the Vocational High School teachers in Serang City that is observed has characters and characteristics that are appropriate to the developing environment in each school that is the object research. Qualitatively, the results obtained in the field have the same tendency with the results of the teacher's visionary leadership in quantitative terms.

Based on the description above, it can be concluded that the higher the Visionary Leadership of the Teacher, the better the Teacher's Performance results in the school. Thus, the findings of the facts and data in the analysis of the research that the author is doing further strengthen and support the facts that exist and before about the positive relationship between the visionary leadership of Teacher with Teacher Performance.

\subsection{The Relationship between Self-Concept, Teamwork and Visionary Leadership Together with Vocational High School Teacher Performance The}

Results of hypothesis testing show the correlation coefficient value between Teacher's Self Concept, Teacher Teamwork and Teacher Visionary Leadership together towards Teacher Performance is equal to 0.782 , this shows that any increase in scores of Teacher's Self Concept, Teacher Teamwork and Teacher Visionary Leadership together improve Teacher Performance. The relationship between the variables of self-concept, teamwork and teacher visionary leadership together with teacher performance is shown by the correlation coefficient $r_{\mathrm{y} .1}=0.884$ with the coefficient of determination $r_{y .10 .782}^{2}=$. This means that the self-concept, teamwork and visionary leadership of teachers together contributed $78.2 \%$ to teacher performance, while $21.8 \%$ of teacher performance was influenced by other factors.

The findings obtained in this study indicate that if the teacher in his work is able to conceptualize himself and understand the extent of his existence as a teacher through a variety of experiences, the teacher will easily be able to arrange programs, manage, master and organize matters relating to indicators of performance achievement in accordance with educational objectives. In its application, teacher performance can be achieved to the maximum if the teacher himself can recognize the positive 
and negative actions contained in himself and if it is done consistently and continuously it will result in the realization of a performance in the form of a quantity of work and good quality of work and according to expectations.

This is in line with the theory put forward by Springer (2010) which states that self-concept reflects one's tendency towards various aspects of his actions both positively and negatively. In the social learning theory approach, negative self-concepts are defined about the number of negative selfreinforcements. Instead, the positive self-concept is defined in relation to the number of positive selfreinforcements. Meanwhile, according to the theory put forward by Burns in Oktaviana's study, a positive self-concept can be equated with a positive self-evaluation, positive self-esteem, positive selfesteem and positive self-acceptance. While negative self-concepts will reflect negative evaluations, self-loathing, feelings of inferiority and the absence of feelings that value personal and selfacceptance.

Likewise, teacher teamwork as suggested by Harris (2014), which states that if teamwork is carried out well, there are many benefits such as there are many sources or ways to solve problems, increase the creativity and innovation of members, improve quality and decision making, having a better commitment to work, having high motivation through joint actions, better control and discipline at work, and increased self-satisfaction. Team members must be flexible enough to adapt to the work environment and must be cooperative where goals are achieved through collaboration and interdependence to achieve goals.

Besides, the teacher's performance will run well if the teacher's teamwork goes well. Because in teamwork teachers are required to be responsible and work together to improve well work performance. This is following Robbert's statement which argues that teamwork is an effort to raise awareness and support to work together in synergy in a team that knows each other, understands, is responsible for building trust.

However, the coefficient of determination is higher if the three independent variables in this study are the variables of self-concept, teamwork, and visionary leadership together to the teacher performance variable at school, which is equal to 0.884 . This implies that the concept of self, teamwork, visionary leadership together is a factor that can achieve maximum teacher performance. Also, the results obtained from this study indicate that $88.4 \%$ of teacher performance is the result of the work of selfconcept variables, teamwork, and visionary leadership together on teacher performance.

This is reinforced by the results of qualitative research on the focus of qualitative research which shows that self-concept, teamwork, and visionary leadership with teacher performance shows a positive and significant relationship with teacher performance. This can be seen from the phenomenon of the implementation of the main tasks and the work of teachers who are supported by good teamwork between teachers and students, teachers and colleagues, as well as teachers and leaders or principals. Besides that, good leadership during class and social environmentis in accordance with the objectives to be achieved.

Other factors that are related are revealed through the focus of qualitative research: Are there other factors beyond the Self Concept, Teamwork, Visionary Leadership of Teachers and Teacher Performance in Vocational Schools in Serang City. Other factors that are thought to be related to the achievement of performance based on observations, interviews and qualitative research documentation in the field include: 1) Behavioral Self, 2) Judging, 3) Identity, 4) Physical Self, 5) Futuristic, 6) Interpreter Talk, 7) Planner, 8) Trainer, 9) Aligned On Purpose, 10) Process of teamwork development, 11) Intensive Communication, 12) Focused On Task, 13) Classroom procedure, 14) Teaching Evaluation, 15), Teaching plans and materials 16) interpersonal skills, it is estimated also related to improving the performance of teachers in schools in carrying out their duties.

\subsection{SITOREM Analysis}




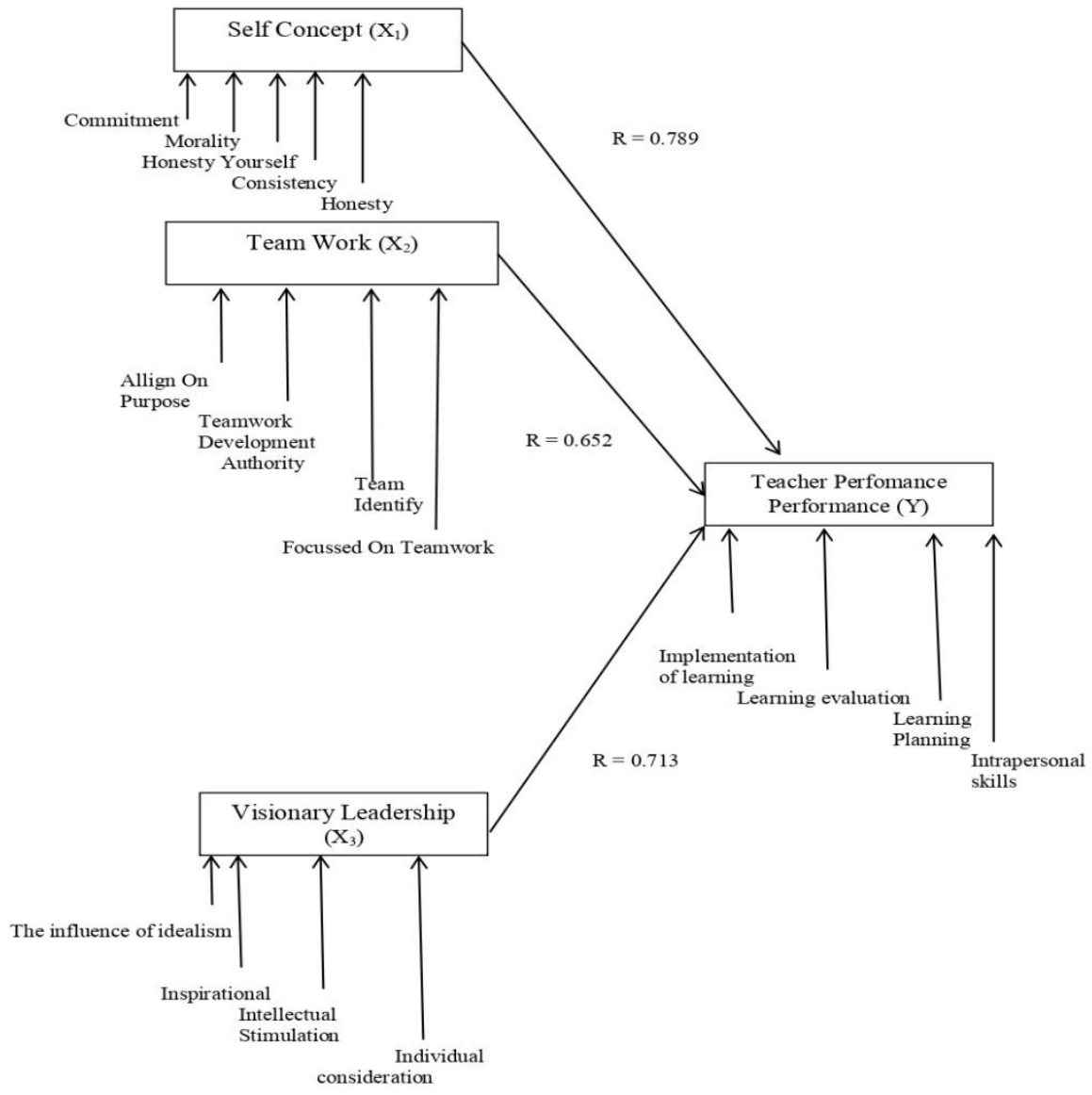

Figure1: Analysis SITOREM (Scientific Identification Theory for Operational Research in Education)

\section{CONCLUSION}

Based on the results of research at the quantitative stage and qualitative research stage it can be concluded that this study has found efforts to improve Teacher Performance, based on the identification of:

- There is a positive and very significant relationship between self-concept and Teacher performance, meaning that the higher the Principal's self-concept will lead to an increase in Teacher Performance and vice versa.

- There is a positive and very significant relationship between Teamwork and Teacher Performance, meaning that the higher Teamwork Team Principal will lead to an increase in Teacher Performance and vice versa.

- There is a positive and very significant relationship between Visionary Leadership and Teacher Performance, which means that the higher the Visionary Leadership of the Principal will lead to an increase in Teacher Performance and vice versa.

- There is a positive and very significant relationship between self-concept, Teamwork and Visionary Leadership together with Teacher Performance, which means that the higher the selfconcept, Teamwork and Visionary Leadership of School Principals together will lead to an increase in Teacher Performance and vice versa.

\section{REFERENCES}

[1] Al-Sharafi, H., \& Rajiani, I. (2013). Leadership practices and talent turnover: Study on Yemeni organisations. Business and Management Research, 2(3), 60-67.

[2] Dee, T. S., \& Wyckoff, J. (2015). Incentives, selection, and teacher performance: Evidence from IMPACT. Journal of Policy Analysis and Management, 34(2), 267-297.

[3] Darling-Hammond, L. (2010). Evaluating teacher effectiveness: How teacher performance assessments can measure and improve teaching. Center for American Progress. 
[4] Hardhienata, S., 2017, January.The development of scientific identification theory to conduct operation research in education management. In IOP Conference Series: Materials Science and Engineering (Vol. 166, No. 1, p. 012007). IOP Publishing.

[5] Green, J., Liem, G. A. D., Martin, A. J., Colmar, S., Marsh, H. W., \&McInerney, D. (2012). Academic motivation, self-concept, engagement, and performance in high school: Key processes from a longitudinal perspective. Journal of adolescence, 35(5), 1111-1122.

[6] Gueldenzoph Snyder, L. (2009). Teaching teams about teamwork: Preparation, practice, and performance review. Business Communication Quarterly, 72(1), 74-79.

[7] Harris, D. N., \& Sass, T. R. (2014). Skills, productivity and the evaluation of teacher performance. Economics of Education Review, 40, 183-204.

[8] Lerner, S., Magrane, D., \& Friedman, E. (2009).Teaching teamwork in medical education. Mount Sinai Journal of Medicine: A Journal of Translational and Personalized Medicine: A Journal of Translational and Personalized Medicine, 76(4), 318-329.

[9] Taylor, E. S., \& Tyler, J. H. (2012).The effect of evaluation on teacher performance. American Economic Review, 102(7), 3628-51.

[10] Muralidharan, K., \&Sundararaman, V. (2011). Teacher performance pay: Experimental evidence from India. Journal of political Economy, 119(1), 39-77.

[11] Senior, C., Cubbidge, R., Riebe, L., Roepen, D., Santarelli, B., \&Marchioro, G. (2010). Teamwork: effectively teaching an employability skill. Education+ Training.

[12] Springer, M. G., \& Gardner, C. D. (2010). Teacher pay for performance: Context, status, and direction. Phi Delta Kappan, 91(8), 8-15.

[13] Wang, F. J., Chich-Jen, S., \& Mei-Ling, T. (2010). Effect of leadership style on organizational performance as viewed from human resource management strategy. African Journal of Business Management, 4(18), 3924-3936.

Citation: H. TB. Urip Henus Surawardhana, et.al. "Sequential Explanatory Analysis of High School Teachers' Performance Observed From Self-Concepts, Teamwork and Visionary Leadership" International Journal of Managerial Studies and Research (IJMSR), vol 7, no. 12, 2019, pp. 16-23. doi: http://dx.doi.org/10. 20431/2349-0349.0712003.

Copyright: (C) 2019 Authors. This is an open-access article distributed under the terms of the Creative Commons Attribution License, which permits unrestricted use, distribution, and reproduction in any medium, provided the original author and source are credited. 